\title{
KEMAMPUAN PEMECAHAN MASALAH SISWA PADA MATERI PROGRAM LINEAR MELALUI TAHAPAN NEWMAN
}

\author{
Choirul Fachis $^{1}$, Dewi Azizah ${ }^{2}$, Nurina Hidayah ${ }^{3}$ \\ cfachis@gmail.com, azizah.0186@gmail.com, nurinahidayah.matematika@gmail.com \\ ${ }^{1,2,3}$ Universitas Pekalongan
}

\begin{abstract}
The purpose of this article is to describe students' problem solving abilities in completing linear programs through the Newman stages. This article uses qualitative. Data collection was obtained from the method of setting, testing, and interviewing. There are 36 students in class IX PS 2 as the subject of this article. The subject's abilities are categorized as high, medium, and low. Descriptive analysis was obtained from 9 students who represented each level. Test the validity of the data by triangulation. The results of the analysis obtained an average problem solving ability using the Newman stage, namely the ability to read problems $85.6 \%$ classified well, the ability to solve problems $80 \%$ classified well, the ability to transform $82.59 \%$ classified well, the ability to process $73.3 \%$ classified good, the ability to solve answers $67.7 \%$ classified sufficiently. Of the 8 levels of ability obtained by 8 high-skilled students require new procedures well in solving problems, 24 capable students are having difficulty in the process of problem transformation, and 4 low-ability students are unable to handle new procedures.
\end{abstract}

Keywords: problem solving ability, the Newman's procedure

\begin{abstract}
Abstrak
Tujuan artikel ini untuk mendeskripsikan kemampuan pemecahan masalah siswa dalam menyelesaikan permasalahan program linear melalui tahapan Newman. Artikel ini menggunakan pendekatan kualitatif. Pengumpulan data diperoleh dari metode dokumentasi, tes, dan wawancara. Ada 36 siswa kelas IX PS 2 sebagai subjek pada artikel ini. Kemampuan subjek dikategorikan dengan tinggi, sedang, dan rendah. Analisis deskriptif diperoleh dari 9 siswa yang mewakili masing-masing tingkat. Uji keabsahan data dengan triangulasi. Hasil analisis diperoleh rata-rata kemampuan pemecahan masalah menggunakan tahapan Newman yaitu kemampuan dalam membaca masalah $85,6 \%$ berklasifikasi baik, kemampuan dalam memahami masalah $80 \%$ berklasifikasi baik, kemampuan mentransformasikan 82,59\% berklasifikasi baik, kemampuan memproses 73,3\% berklasifikasi baik, kemampuan penulisan jawaban $67,7 \%$ berklasifikasi cukup. Dari ketiga tingkat kemampuan siswa diperoleh 8 siswa berkemampuan tinggi mampu menerapkan prosedur Newman dengan baik dalam menyelesaikan permasalahan, 24 siswa berkemampuan sedang mengalami kesulitan dalam melakukan proses transformasi masalah, dan 4 siswa berkemampuan rendah belum mampu memahami prosedur Newman dalam menyelesaikan permasalahan matematika.
\end{abstract}

Kata kunci: kemampuan pemecahan masalah, prosedur Newman

\section{ARTICLE HISTORY:}

Received: 24 Februari 2020, Revised: 8 Maret 2020,

Accepted: 4 April 2020, Onlinefirst: 7 April 2020 


\section{PENDAHULUAN}

Kemampuan pemecahan masalah merupakan kemampuan untuk mencari solusi dari masalah yang siswa hadapi. Salah satu tujuan yang harus dicapai siswa setelah mempelajari matematika yaitu memiliki kemampuan pemecahan masalah (Utami dan Wutsqa, 2017), sehingga kemampuan pemecahan masalah menjadi bagian yang penting dan siswa harus memiliki. Hal ini sepadan dengan prinsip pada kurikulum 2013 yang menyatakan bahwa pemecahan masalah merupakan bagian penting dari pembelajaran matematika dan kemampuan pemecahan masalah menjadi hal yang harus dicapai siswa. Guru berharap jika siswa memiliki kemampuan pemecahan masalah maka siswa mampu memecahkan permasalahan khususnya pada masalah matematika. Pada umumnya, soal cerita merupakan permasalahan untuk mengukur kemampuan siswa dalam memecahkan masalah.

Menurut Paridjo dalam Kartikasari dan Masduki (2017) hambatan siswa dalam mencari solusi pada soal matematika yang berbentuk cerita adalah kesulitan dalam memahami isi dan maksud soalnya, menentukan unsur-unsur yang diketahui untuk membuat model matematikanya dan memecahkan model tersebut. Kesulitan ini dirasa oleh siswa pada semua jenjang pendidikan, tidak hanya siswa sekolah menengah. Kesulitan tersebut karena siswa tidak telaten dan teliti dalam memahami isi soal sehingga siswa kesulitan membuat model matematikanya dan tidak dapat menyelesaikan permasalahan tersebut dengan konsep yang tepat. Kesulitan-kesulitan tersebut dapat menyebabkan rendahnya kemampuan pemecahan masalah siswa.

Permasalahan program linear merupakan salah satu contoh soal yang membutuhkan kemampuan siswa dalam memecahkan masalah. Soedjadi dalam Wijaya (2012) menyebutkan tahapan-tahapan dalam memecahkan soal cerita khususnya matematika, yaitu membaca dengan cermat isi soal untuk memahami makna setiap kalimat, memisalkan dan menyatakan, apa yang diketahui dan ditanyakan di soal, konsep apa yang dibutuhkan, membuat dan menyelesaikan model matematika, mengoreksi kembali jawaban tersebut dengan cara yang berbeda. Sehingga dengan langkah-langkah tersebut siswa dapat memecahkan persoalan maetematika dengan mudah dan tepat.

Rendahnya siswa dalam kemampuan pemecahan masalah dapat dilihat menggunakan tahapan Newman. Tahapan ini untuk menyelidiki penyebab dan 
kesalahan siswa dalam memecahkan permasalahan program linear. Newman menyatakan jika siswa harus bekerja melalui 5 langkah dalam menyelesaikan persoalan matematika yaitu membaca, memahami, mentransformasi, keterampilan dalam memproses, dan memberi kode (Karnasih, 2015). Dengan siswa mengetahui jenis kesalahannya dalam memecahkan masalah program linear maka dapat meminimalkan kesalahan yang sama sehingga mampu meningkatkan daya serap siswa. Rumusan masalah artikel ini adalah bagaimana tingkat kemampuan pemecahan masalah siswa kelas XI SMK N 1 Batang dalam menyelesaikan persoalan matematika materi program linear menggunakan tahapan Newman?.

\section{METODE PENELITIAN}

Artikel ini merupakan penelitian deskriptif dengan menggunakan pendekatan kualitatif. Data diperoleh dengan menggunakan metode dokumentasi, tes, maupun wawancara. Subjek pada pada artikel ini adalah 36 siswa kelas XI Perbankan 2 yang selanjutnya dikelompokkan menjadi kemampuan tinggi, sedang, dan rendah. Sembilan siswa mewakili dari masing-masing tingkat kemampuan untuk diwawancarai sebagai analisis deskripsinya.

Data dan sumber data dalam penelitian ini diperoleh dari hasil pre tes dan post tes kemampuan pemecahan masalah dan wawancara terhadap siswa yang mewakili masingmasing kemampuan. Data tersebut diperoleh dari hasil analisis tes evaluasi kemampuan pemecahan masalah materi program linear. Langkah-langkah analisis hasil tes evaluasi tersebut sebagai berikut.

1. Membuat pedoman penskoran

Pedoman penskoran dalam memecahkan masalah pada setiap butir tes pemecahan masalah materi program linear adalah sebagai berikut.

Tabel 1. Kriteria Penskoran Tahapan Newman.

(Visitasari dan Siswono, 2012)

\begin{tabular}{|c|c|c|c|}
\hline $\begin{array}{l}\text { Tahapan } \\
\text { Newman }\end{array}$ & Reaksi Terhadap Soal & Kriteria & Skor \\
\hline \multirow{2}{*}{$\begin{array}{l}\text { Membaca } \\
\text { masalah }\end{array}$} & $\begin{array}{l}\text { Siswa mengerti semua istilah, kata-kata, kalimat, dan } \\
\text { simbol mencapai } 85 \% \text {. }\end{array}$ & Baik & 3 \\
\hline & $\begin{array}{l}\text { Siswa mengerti semua istilah, kata-kata, kalimat dan } \\
\text { simbol mencapai } 60 \%-85 \%\end{array}$ & Cukup & 2 \\
\hline
\end{tabular}




\begin{tabular}{|c|c|c|c|}
\hline & $\begin{array}{l}\text { Siswa mengerti semua istilah, kata-kata, kalimat dan } \\
\text { simbol mencapai } 35 \%-60 \%\end{array}$ & Kurang & 1 \\
\hline & $\begin{array}{l}\text { Siswa mengerti semua istilah, kata-kata, kalimat dan } \\
\text { simbol kurang dari dari } 35 \%\end{array}$ & $\begin{array}{l}\text { Sangat } \\
\text { Kurang }\end{array}$ & 0 \\
\hline \multirow{5}{*}{$\begin{array}{l}\text { Memahami } \\
\text { Masalah }\end{array}$} & $\begin{array}{l}\text { Siswa menuliskan apa yang diketahui dan diminta } \\
\text { dengan tepat dan menggunakan bahasanya sendiri }\end{array}$ & Baik & 3 \\
\hline & $\begin{array}{l}\text { Siswa menuliskan beberapa yang diketahui dan } \\
\text { diminta dengan tepat }\end{array}$ & Cukup & 2 \\
\hline & $\begin{array}{l}\text { Siswa tidak menuliskan apa yang diketahui dan } \\
\text { menuliskan yang ditanya dengan tepat }\end{array}$ & \multirow{2}{*}{ Kurang } & \multirow{2}{*}{1} \\
\hline & $\begin{array}{l}\text { Siswa menuliskan apa yang diketahui dan ditanya } \\
\text { kurang tepat }\end{array}$ & & \\
\hline & $\begin{array}{l}\text { Siswa tidak menuliskan apa yang diketahui dan } \\
\text { ditanyakan }\end{array}$ & $\begin{array}{l}\text { Sangat } \\
\text { Kurang }\end{array}$ & 0 \\
\hline \multirow{4}{*}{$\begin{array}{l}\text { Transformasi } \\
\text { Masalah }\end{array}$} & $\begin{array}{l}\text { Strategi yang digunakan benar dan } \\
\text { mengarah ke jawaban yang benar juga. }\end{array}$ & Baik & 3 \\
\hline & $\begin{array}{l}\text { Strategi yang digunakan benar tetapi tidak dapat } \\
\text { dilanjutkan atau salah langkah (buntu) sehingga } \\
\text { jawaban salah }\end{array}$ & Cukup & 2 \\
\hline & $\begin{array}{l}\text { Strategi atau pemodelan matematika yang digunakan } \\
\text { tidak jelas atau relevan }\end{array}$ & Kurang & 1 \\
\hline & $\begin{array}{l}\text { Tidak ada strategi penyelesaian atau pemodelan } \\
\text { matematika yang tepat }\end{array}$ & $\begin{array}{l}\text { Sangat } \\
\text { Kurang }\end{array}$ & 0 \\
\hline \multirow{4}{*}{$\begin{array}{c}\text { Ketrampilan } \\
\text { Proses/ } \\
\text { Prosedur }\end{array}$} & $\begin{array}{l}\text { Prosedur yang digunakan benar dan jawabannya juga } \\
\text { benar serta mampu menjelaskan alasan } \\
\text { pemecahannya dengan jelas dan benar. }\end{array}$ & Baik & 3 \\
\hline & $\begin{array}{l}\text { Prosedur yang digunakan benar dan mengarah pada } \\
\text { kesalahan perhitungan atau jawaban yang salah }\end{array}$ & Cukup & 2 \\
\hline & Ada penyelesaian tetapi prosedur tidak jelas. & Kurang & 1 \\
\hline & Tidak ada penyelesaian & $\begin{array}{l}\text { Sangat } \\
\text { Kurang }\end{array}$ & 0 \\
\hline \multirow{4}{*}{$\begin{array}{l}\text { Penulisan } \\
\text { jawaban }\end{array}$} & $\begin{array}{l}\text { Mengecek kembali dengan cara yang berbeda dan } \\
\text { membuat kesimpulan yang tepat }\end{array}$ & Baik & 3 \\
\hline & $\begin{array}{l}\text { Mengecek kembali dengan cara yang berbeda namun } \\
\text { kesimpulan yang diberikan kurang tepat }\end{array}$ & Cukup & 2 \\
\hline & $\begin{array}{l}\text { Mengecek kembali dengan cara yang berbeda namun } \\
\text { tidak ada kesimpulan }\end{array}$ & Kurang & 1 \\
\hline & Tidak ada pengecekan dan kesimpulan & $\begin{array}{l}\text { Sangat } \\
\text { Kurang }\end{array}$ & 0 \\
\hline
\end{tabular}

2. Mencari rata-rata skor kemampuan pemecahan masalah

Dari hasil analisis pada tabel penskoran tahapan Newman kemudian dicari ratarata skor kemampuan pemecahan masalah matematika pada masing-masing subjek berdasarkan tahapan Newman dengan rumus berikut.

$$
\overline{\mathrm{x}}=\frac{\sum \mathrm{x}_{\mathrm{i}}}{\mathrm{n}}
$$

(Sudjana, 2005) 
Keterangan:

$\overline{\mathrm{x}}=$ Rata-rata untuk skor siswa pada masing-masing tahapan Newman

$\mathrm{x}_{\mathrm{i}}=$ Nilai akhir siswa ke-i

$\mathrm{n}=$ Banyaknya siswa

3. Menentukan kualifikasi dari hasil rata-rata kemampuan pemecahan masalah matematika.

Setelah dilakukan proses perhitungan rata-rata skor kemampuan pemecahan masalah siswa, kemudian menentukan persentase dan kualifikasi menggunakan tahapan analisis Newman terhadap skor maksimal pada tes pemecahan masalah program linear. Cara mencari persentase dan menentukan kualifikasi memecahkan masalah dengan tahapan Newman sebagai berikut

$$
\mathrm{P}=\frac{\overline{\mathrm{x}} \times 100 \%}{3}
$$

(Visitasari dan Siswono, 2013)

Tabel 2. Kualifikasi Persentase Tahapan Newman

\begin{tabular}{ll}
\hline \multicolumn{1}{c}{ Persentase $(\mathrm{P})$} & \multicolumn{1}{c}{ Kualifikasi } \\
\hline $75<\mathrm{P} \leq 100$ & Baik \\
\hline $50<\mathrm{P} \leq 75$ & Cukup \\
\hline $25<\mathrm{P} \leq 50$ & Kurang \\
\hline $0 \leq \mathrm{P} \leq 25$ & Sangat Kurang \\
\hline
\end{tabular}

4. Pengelompokkan tingkatan kemampuan pemecahan masalah

Hasil analisis kemampuan pemecahan masalah program linear pada tiap tahapan Newman kemudian digunakan untuk pengelompokkan subjek ke dalam tiga kategori kemampuan yaitu tinggi, sedang dan rendah. Hasil tersebut digunakan untuk menentukan subjek yang akan diwawancarai berdasarkan masing-masing kategori. Kriteria pengelompokan kemampuan siswa adalah sebagai berikut.

a. Tinggi jika nilai $\geq 88$

b. Sedang jika nilai $59<$ nilai $<88$

c. Rendah jika nilai $\leq 59$

5. Menentukan subjek wawancara

Dari hasil pengelompokan siswa ke dalam tiga kategori diperoleh subjek wawancara yang terdiri sembilan siswa dari 3 kelompok yaitu subjek berkemampuan tinggi yaitu S1, S2, dan S3; subjek berkemampuan sedang yaitu S4, S5 dan S6; dan 
subjek berkemampuan rendah yaitu S7, S8, dan S9.

\section{HASIL DAN PEMBAHASAN}

Berdasarkan hasil analisis kemampuan 36 siswa dalam memecahkan masalah program linier dengan menggunakan tahapan Newman diperoleh 8 siswa berkemampuan tinggi, 24 siswa berkemampuan sedang dan 4 siswa berkemampuan rendah dengan rincian sebagai berikut.

a. Kemampuan tingkat tinggi

Dalam tingkat ini siswa mampu menerapkan prosedur Newman dalam menyelesaikan program linear dengan baik, tetapi masih ditemui kesalahan pada penulisan jawaban (Enconding) yang disebabkan kurangnya ketelitian siswa dan waktu yang terbatas. Rata-rata kemampuan siswa dalam menyelesaikan masalah program linier berdasarkan tahapan Newman dapat dilihat pada tabel berikut.

Tabel 3. Kemampuan SiswaTingkat Tinggi

\begin{tabular}{lcc}
\hline \multicolumn{1}{c}{ Tahapan Newman } & Persentase & Kriteria \\
\hline Reading & $94,2 \%$ & Baik \\
\hline Comprehension & $93,2 \%$ & Baik \\
\hline Transformation & $92,5 \%$ & Baik \\
\hline Process Skill & $90 \%$ & Baik \\
\hline Encoding & $80 \%$ & Baik \\
\hline
\end{tabular}

Berdasarkan tabel di atas diperoleh rata-rata kesalahan siswa dalam membaca masalah sebesar 5,8\%, memahami masalah sebesar 6,8\%, transformasi masalah sebesar 7,5, keterampilan memproses sebesar 10\%, dan penulisan jawaban sebesar 20\%. Dalam tingkat ini siswa mampu menerapkan prosedur Newman dalam menyelesaikan permasalahan program linear dengan baik. Namun masih ditemui kesalahan pada penulisan jawaban yang disebabkan kurangnya ketelitian siswa dan waktu yang terbatas. Hasil wawancara dengan subjek S1, S2 dan S3 diperoleh sebagai beikut.

1. Subjek S1 mampu menerapkan prosedur Newman dalam menyelesaikan persoalan matematika dengan tepat tanpa adanya kesalahan. Hal tersebut dikarenakan subjek S1 sudah terbiasa dalam menyelesaikan permasalahan menggunakan langkah pemecahan masalah.

2. Subjek S2 mampu menerapkan prosedur Newman dalam menyelesaikan masalah dengan baik dan benar. Namun terjadi kesalahan pada tahap mentransformasikan 
soal dalam memecahkan soal nomor 2. Penyebab dari subjek S2 melakukan kesalahan karena terburu-buru dalam menyelesaikan masalah dengan terbatasnya waktu yang disediakan sehingga subjek S2 dalam melakukan proses perhitungan tidak cermat dan teliti.

3. Subjek S3 berusaha menerapkan sesuai tahapan Newman saat memecahkan masalah program linear. Namun terjadi kesalahan pada tahap menyimpulkan dalam mengerjakan soal nomor 4. Subjek S3 melakukan kesalahan karena dalam mengerjakan soal terburu-buru sehingga subjek S3 dalam melakukan tahap menyimpulkan jawaban akhir tidak telili.

Hasil penelitian pada tingkat kemampuan tinggi relevan dengan penelitian Visitasari dan Siswono (2013) yang menyatakan bahwa kemampuan siswa dalam memecahkan persoalan matematika menunjukkan klasifikasi baik. Hal ini dikarenakan subjek telah mampu menguasai dan mengaplikasikan tahapan penyelesaian soal menggunakan tahapan Newman dengan baik.

b. Kemampuan tingkat sedang

Dalam tingkat ini siswa mengalami kesulitan menerapkan prosedur Newman dalam menyelesaikan masalah program linear. Hal tersebut dilihat dari banyaknya kesalahan siswa pada transformasi masalah (transformation) yang disebabkan siswa tidak mampu mengolah apa yang diketahui dari soal untuk dijadikan bahan untuk memperoleh jawaban dari soal cerita tersebut. Rata-rata hasil kemampuan siswa dalam menyelesaikan masalah program linear menggunakan tahapan Newman dapat dilihat pada tabel berikut.

Tabel 4. Kemampuan Siswa Tingkat Sedang

\begin{tabular}{lcc}
\hline \multicolumn{1}{c}{ Tahapan Analisis Newman } & Persentase & Kriteria \\
\hline Reading & $84,2 \%$ & Baik \\
\hline Comprehension & $68,1 \%$ & Cukup \\
\hline Transformation & $67,5 \%$ & Cukup \\
\hline Process Skill & $76,9 \%$ & Cukup \\
\hline Encoding & $55,3 \%$ & Cukup \\
\hline
\end{tabular}

Berdasarkan tabel tersebut, diperoleh rata-rata bahwa kesalahan siswa dalam membaca masalah 31,9\%, memahami masalah sebesar 6,8\%, transformasi masalah sebesar 32,5\%, kesalahan siswa dalam ketrampilan memproses sebesar 3,1\%, dan 
penulisan jawaban sebesar 20\%. Hasil wawancara dengan subjek S4, S5 dan S6 diperoleh sebagai beikut.

1. Subjek S4 mampu menerapkan prosedur Newman dalam menyelesaikan masalah soal cerita namun mengalami kesalahan dalam tahap kemampuan memproses penyelesaian pada soal nomor 5. Subjek S4 melakukan kesalahan dalam memecahkan persoalan pemecahan masalah karena subjek S4 belum sepenuhnya memahami masalah. Selain itu, S4 juga kurang teliti sehingga kurang tepat dalam menyelesaikan masalah.

2. Subjek S5 dan S6 mampu menyelesikan kemampuan memproses dengan baik dan benar, namun kurang terbiasa dengan menuliskan jawaban sesuai dengan prosedur menyelesaikan pemechan masalah. Subjek S5 dan S6 hanya melakukan kemampuan memproses tanpa melakukan tahap memahami dan transformasi.

Pada tingkat ini, siswa mengalami kesulitan menerapkan prosedur Newman dalam menyelesaikan permasalahan. Kesulitan tersebut dapat dilihat dari banyak siswa yang belum dapat mentransformasikan masalah (transformation) yang disebabkan siswa belum dapat menentukan komponen yang diketahui dari permasalahan untuk dijadikan bahan memperoleh jawaban dari permasalahan tersebut.

c. Kemampuan pemecahan masalah tingkat rendah

Pada tingkat ini siswa belum mampu menerapkan prosedur newman dalam menyelesaikan permasalahan program linear dengan baik. Hal tersebut dapat dilihat dari banyaknya kesalahan siswa pada tahap memahami masalah (comprehension) yang secara langsung berakibat tidak bisa melanjutkan ketahapan selanjutnya. Rata-rata kemampuan siswa dalam menyelesaikan masalah program linear menggunakan tahapan Newman dapat dilihat pada tabel berikut.

Tabel 5. Kemampuan Siswa Tingkat Rendah

\begin{tabular}{ccc}
\hline Tahapan Analisis Newman & Persentase & Kriteria \\
\hline Reading & $78,8 \%$ & Baik \\
\hline Comprehension & $33,5 \%$ & Kurang \\
\hline Transformation & $35 \%$ & Kurang \\
\hline Process Skil & $45 \%$ & Kurang \\
\hline Encoding & $23,3 \%$ & Kurang \\
\hline
\end{tabular}


Berdasarkan tabel tersebut, diperoleh rata-rata kesalahan siswa dalam membaca masalah sebesar 21,2\%, kesalahan memahami masalah sebesar 66,5\%, kesalahan transformasi masalah sebesar $65 \%$, kesalahan siswa dalam ketrampilan memproses sebesar $65 \%$, dan kesalahan penulisan jawaban sebesar 76,7\%.

Berdasarkan hasil analisis tes diperoleh kemampuan pemecahan masalah program linear melalui tahapan Newman yaitu kemampuan siswa dalam membaca masalah (reading) 85,6\% dengan klasifikasi baik, memahami masalah (comprehention) $80 \%$ dengan klasifikasi baik, mentransformasikan masalah (transformation) 82,59 \% dengan klasifikasi baik, keterampilan memproses (process skil) 73,3\% dengan klasifikasi baik, dan menggunakan penulisan jawaban (encoding) 67,7\%. Hasil wawancara dengan subjek S7, S8 dan S9 diperoleh sebagai beikut.

1. Subjek S7 belum bisa menerapkan prosedur Newman saat mengerjakan soal cerita matematika. Hal tersebut dikarenakan subjek S7 tidak terbiasa menyelesaikan masalah menggunakan langkah-langkah pemecahan masalah. Dalam mengerjakan soal nomor 5 tidak menyelesaikan masalah apapun atau sama sekali tidak melakukan kemampuan memproses, hal tersebut dikarenakan subjek S7 belum dapat memahami isi kalimat yang terdapat pada soal sehingga tidak mengetahui bagaimana mentransformasikan permasalahan ke model matematika.

2. Subjek S8 belum bisa menerapkan prosedur Newman saat mengerjakan soal cerita matematika. Subjek S8 hanya mampu memahami isi soal saja dengan menuliskan apa yang diketahui dan ditanyakan, namun sama sekali tidak bisa melakukan kemampuan memproses. Kesalahan S8 dalam meyelesaikan masalah matematika karena belum sepenuhnya memahami materi program linier dan tidak dapat menyelesaikan masalah soal cerita karena dianggap rumit. Sehingga tidak dapat menuliskan jawaban akhir karena tidak mampu melakukan kemampuan memproses.

3. Subjek S9 belum mampu menerapkan prosedur Newman saat mengerjakan soal cerita matematika. Subjek S9 hanya mampu memahami isi soal saja dengan menuliskan apa yang diketahui dan ditanyakan, namun subjek S9 sama sekali tidak bisa melakukan kemampuan memproses dan menuliskan jawaban .

Pada tingkat ini, kemampuan siswa dalam memecahkan persoalan program linear termasuk dalam klasifikasi cukup. Hasil artikel ini relevan dengan artikel Rohmah dan 
Sugeng (2018) menyatakan bahwa kesalahan yang dialami oleh siswa dalam masalah matematika melengkapi sistem persamaan linear dua variabel yaitudalam membaca sebesar 4,35\%, memahami 17,39\%, mentransformasikan 34,78\%, menetukan prosedur 23,91\%, dan menuliskan jawaban $19,57 \%$.

\section{SIMPULAN DAN SARAN}

Berdasarkan hasil analisis tes kemampuan siswa menyelesaikan permasalahan program linear dengan tahapan Newman yang diberikan kepada 36 siswa kelas XI SMK N 1 Batang dapat diperoleh beberapa simpulan sebagai berikut.

1. Kemampuan siswa membaca masalah (reading) 85,6\% dengan klasifikasi baik.

2. Kemampuan siswa dalam memahami masalah (comprehention) $80 \%$ dengan klasifikasi baik.

3. Kemampuan siswa dalam mentransformasikan masalah (transformation) 82,59\% dengan klasifikasi baik.

4. Kemampuan siswa dalam menggunakan keterampilan memproses (process skill) 73,3\% dengan klasifikasi baik.

5. Kemampuan siswa dalam menulis jawaban (encoding) $67,7 \%$ dengan klasifikasi cukup.

Kemudian beberapa saran dari artikel ini sebagai berikut.

1. Guru perlu memperhatikan kesalahan-kesalahan siswa dalam menjawab tes pemecahan masalah untuk menemukan solusi dari kesulitan-kesulitan yang dihadapi siswa agar tidak melakukan kesalahan yang sama.

2. Perlu dilakukan penelitian lanjutan dengan mengembangkan subjek dan skala lebih besar dari beberapa sekolah untuk melihat kemampuan siswa dalam memecahkan masalah.

\section{DAFTAR PUSTAKA}

Karnasih, Ida. 2015. Analisis Kesalahan Newman Pada Soal Cerita Matematis (Newman's Error Analysis in Mathematical Word Problems). Jurnal PARADIKMA, 8 (1). 37-51.

Kartikasari, R., \& Masduki, S. S. 2017. Analisis Kesulitan Siswa dalam Menyelesaikan Soal Cerita Matematika Pada Siswa SMP. Universitas Muhammadiyah Surakarta. 
Rohmah, Mushlihah dan Sugeng Sutiarso. 2018. Analysis Problem Solving in Mathematical Using Theory Newman. EURASIA Journal of Mathematics, Science and Technology Education, 14 (2), 671-681. doi : 10.12973/ejmste/80630.

Sudjana. 2005. Metode Statistika. Bandung: PT. Tarsito Bandung.

Utami, R. W., \& Wutsqa, D. U. 2017. Analisis Kemampuan Pemecahan Masalah Matematika dan Self-Efficacy Siswa SMP Negeri di Kabupaten Ciamis. Jurnal Riset Pendidikan Matematika, 4(2), 166-175. https://doi.org/10.21831/jrpm.v4i2.14897.

Visitasari, Riska dan Tatag Yuli Eko Siswono. 2013. Kemampuan Siswa Memecahkan Masalah Berbentuk Soal Cerita Aljabar Menggunakan Tahapan Analisis Newman. Jurnal Mathedunes. 2 (2).

Wijaya, Aris Arya, Masriyah. 2012. Analisis Kesalahan Siswa Dalam Menyelesaikan Soal Cerita Materi Sistem Persamaan Linier Dua Variabel. Jurnal Mathedunesa. (Online) Tersedia: http://jurnalmahasiswa.unesa.ac.id/article/2855/30/article.pdf 